\title{
Can Do Very Well
}

National Cancer Institute

\section{Source}

National Cancer Institute. Can Do Very Well. NCI Thesaurus. Code C159755.

An indication that someone can do something quite well. 